\title{
Demographic and Socio-Economic Conditions of the Restructuring of Family Policy in Poland
}

\author{
By Joanna Szczepaniak-Sienniak ${ }^{*}$
}

\begin{abstract}
Contemporary changes of the family imply the need to seek new perspectives in family policy. In Poland, successive reforms and the proposed changes in this area have not yielded the expected results, either in terms of demographic balance, society or the economy of the country. They do not include in full many important aspects, among them the transformation of the family as well as other aspects such as the principle of subsidiarity, the empowerment of families, economic changes (especially in the labor market) and the mutual implications of family policy and the economy. The main objective of the article is to present changes of the family policy model, the dilemmas and the possibility of rebuilding this policy in Poland taking into consideration both the still unresolved problems and risks of family change (de-institutionalization), as well as the new challenges resulting from this state of affairs in demographic as well as social and economic aspects. The background considerations are the models of family policy in other European countries.
\end{abstract}

\section{Introduction}

Like in other European countries, Poland has also witnessed the transformation and disintegration of the family, manifested in such phenomena as the decrease of the married population mainly as a result of divorces or denying marriage, postponing marriage decisions of women and men, the increasing or high rate of divorce, delaying the birth of the first child, the fertility rate falling below replacement rate, shift of maximum fertility from younger to older age groups, the total negation of marriage and/or parenthood and choosing other forms of personal life such as cohabitation (with or without children), single parenthood, living alone with no children (as a single), childless marriage (DINKS, i.e. Double Income No Kids). In the Polish literature, these indicators are considered to be manifestations of deinstitutionalization (de-traditionalization) of the family standing for the devaluation of the traditional family consisting of spouses and children as a basic social unit (Socjologia. Przewodnik encyklopedyczny 2008, p. 168). The phenomena mentioned above that relate to the creation and functioning of the family are the main factors of these processes. They significantly impact fertility, as it is still marriage that remains the most favoured form of

*Assistant Professor, Wroclaw University of Economics, Poland.

https://doi.org/10.30958/ajss.1-4-4

doi=10.30958/ajss.1-4-4 
relationship when having children. Meanwhile the number of such families is decreasing and matrimonial decisions (as well as reproductive ones) are being delayed. In the developed countries this process is considered to have begun in the 1960s, in Poland, however, its origins reach back to the second half of the 1990s. It is also considered to have come along with all the dimensions of the transformation - systemic, economic, cultural, etc. Such changes have significantly altered the role of the family in society, as well as the conditions for its forming and functioning, which influences the contemporary challenges of family policy.

The lack of real and consistently implemented programs is an essential feature of family policy in Poland ${ }^{1}$. It lacks long-term solutions for the formation and functioning of families, especially those of middle-income classes. When making procreative decisions, such families often face the risk of a significant reduction in living standards caused by the lack of a work-life balance (i.e. adequate institutional and fiscal tools, social transfers and services etc.). Gaps and deficiencies in this area usually result from the austerity policy and focusing primarily on the needs of the poorest families, often without the expected outcomes. This situation also results from ideological disputes over the concept of family policy and the lack of conditions for the successful implementation of certain ideas or principles.

Therefore family policy in Poland undoubtedly requires fundamental transformation. The main objective of the article is to present changes of the family policy model, the dilemmas and the possibility of rebuilding this policy in Poland, taking into consideration both the still unresolved problems and the risks of family change (de-institutionalization), as well as the new challenges resulting from this state of affairs in demographic as well as social and economic aspects. The background considerations are the models of family policy in other European countries.

\section{Fertility as a Main Indicator of the De-Institutionalization of the Family in Poland and Other European Countries}

The factors and manifestations of de-institutionalization observed in Polish families are the core issues of these considerations, especially in comparison to the European background. Due to socio-economic diversity and the cultural changes in individual countries, the transformation of the family in Europe is not universal and is proceeding at varying speed. Further in-depth analysis indicates that although this process is not as advanced in Poland as it is in other European countries, it still significantly affects the disproportion between family policy solutions and the actual needs of the families.

The low levels of fertility across Europe attract particular attention in the context of family de-institutionalization. It should be emphasized that in most

${ }^{1}$ For example: Poland has new, well viewed, presidential program of family policy ('Dobry klimat dla rodziny' 2013) but difficult to fully implement due to limited financial resources. 
countries, especially those in relative early transition, fertility has however been restored.

According to Eurostat's biennial reports on the demographic condition of the Community, since 2003 - after a sharp drop in 1980 and at the beginning of 2000 - fertility began to rise in the EU27/EU28: from 1.47 in 2003 to 1.61 children per woman in 2010. After 2010 the discussed rate began to fall and actually now (2012) is 1.58. This is far from the minimum generational renewal (i.e. 2.1) (Figure 1).

Figure 1. Total Fertility Rates in the European Union in 2012

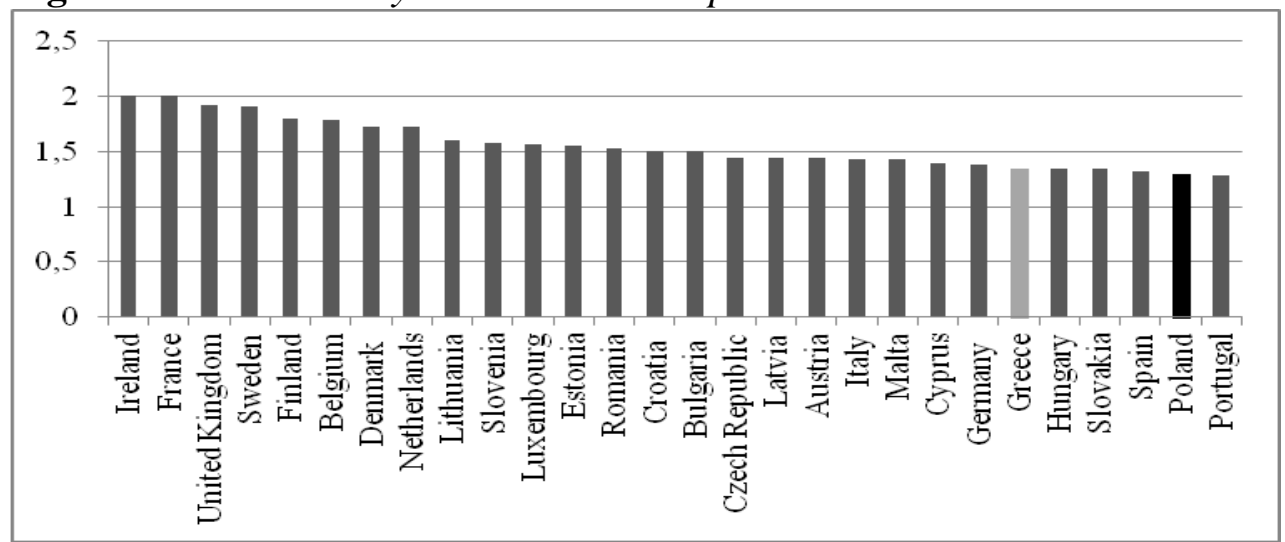

Source: Eurostat Database, http://epp.eurostat.ec.europa.eu

In 2012, Ireland (2.01), France, (2.01), Sweden (1.91) and the United Kingdom (1.92) were the member states with the highest fertility rates. The lowest rates were observed in Portugal (1.28) and Poland (1.30). In 2010-2012, TFR permanently decreased in Belgium, Bulgaria, Denmark, Estonia, Ireland, Greece, Spain, Italy, the Netherlands, Poland, Portugal and Finland. But almost all countries are considering how to prevent this negative trend or raise the level of fertility.

Poland is also among the countries with relatively low fertility which, according to forecasts, will drop to 1.28 in 2014. In recent years - as in other countries - an increase of this indicator was observed (from 1.22 to 1.398 in 2003-2009), whereas in 2010 it was already slightly lower (1.38) and 1.3 in 2011 and 2012 (Eurostat Database; Roczniki Demograficzne GUS, edition the relevant years). The increasing fertility rate was most likely caused by entering reproductive age by generations born in the mid 1980's and therefore it may decline within the next few years. Therefore the biggest challenge remain invariably changes in family policy and, at the same time, its social and economic conditions.

\section{Changes of Family Policy Model in Poland}

The emerging social policy model are key factors that affect the development of family policy (Spicker P. 2008). They set out basic ideas, 
values, assumptions and objectives that should guide specific social activities. They designate the place of the family in social policy, and social policy instruments for the family - their nature and character. They describe the conditions for certain instruments in the context defined by the ideological model, institutional spheres of executive subjectivity (sectors), and areas of interaction (e.g. welfare services). A strategy for families created within the model should clearly identify target groups (family types), the quality and level of social benefits (cash, services, institutions), access to these instruments, responsibilities of the family, financing family policies, etc.

At this point the lack of consensus on an emerging model of social policy emerges - a problem that has been visible from the beginning of the transformation (in 1989). Although some common patterns or trends of various models can be identified, as well as the emergence of the growing role of social services and families as subjects of social policy, clear implementation and execution of policy family cannot be performed.

Shifts in social policy mentioned above refer to abandoning the traditional theory of the welfare state (Stiglitz 2004, p. 10-13; Esping-Andersen 2010, p. 21) towards the concept of the subjective citizen and his/her problems, calling attention to the cooperation of stakeholders, including families, local environments and pushing the state to the back of social policy. This shift is also described as leaving the passive policies of giving "fish" to activisation by supplying a "rod", in which social services should be the key instruments.

In order to better understand the nature of these changes, it is worth recalling that before 1989 social policy was the exclusive domain of the state and the authorities who knew best what people needed (Grewiński \& Kamiński 2007, p. 7) and were considered to be the best organizers of economic and social life. This was manifested by undertaking initiatives to organize professional, personal and family life. At the same time the state guaranteed social services (mainly financial transfers) and services, which were commonly provided on a large scale. These benefits were free or very cheap. The socialist state was the main provider of social services in health, education, culture, childcare, care for the elderly and people with disabilities.

The systemic transformation launched in the 1990's focused on building a free market, a civil society and democracy and brought about substantial changes in the state's responsibilities for basic social needs. The increasing crisis of public finances did not allow for the realization of state obligations to citizens at a satisfactory level. The state began to withdraw from family support and intervention by external institutions.

Due to the administrative reform in 1999, the competences of state institutions were decentralized and most of them have largely been ceded to municipalities (local governments). From the organizational perspective, establishing local family assistance centers, extending their functions and introducing non-governmental organizations that proved to be crucial for families and local communities, were of great significance. It seems that when facing numerous barriers and irregularities in the public sector NGOs are of the greatest importance for improving the living standards of Polish families. 
Thus the responsibility of local authorities, non-state actors and the families themselves for creating satisfactory conditions for families was increased by decentralization. This perspective on social policy assumes that the state is neither able to recognize and fulfill all of the citizens' needs, nor may directly protect them from all social risks (Ibid.). Thus the pluralization of social policy stakeholders occurs when the grassroots initiatives of citizens, families, NGOs, local governments and other actors in the local environment grow stronger. This approach involves ideas characteristic of democratic states: active social policy, civic policy, citizenship, civil society, social capital, localism, welfare society and welfare pluralism.

Researchers seek guidance for the development of family policy instruments in the welfare models of other European countries. In this context it seems useful to classify EU member states' models as follows: Scandinavian, Anglo-Saxon, Continental, South European ${ }^{1}$ (see more in Table 1), and Eastern European since 2004. The latter emerged in the former socialist countries of Central and Eastern Europe, including Poland, and shows trends that determine the implementation of these instruments, i.e.:

1) the more or less radical economic reliance on market mechanisms;

2) abandoning "socialist" social security: full employment, job and wage security, subsidized basic goods and services, expanded corporate social responsibilities;

3) the significant reduction of access to free or low-paid social services limited to low income households only; the range of publicly available programs is shrinking to be increasingly replaced by selective actions;

4) shifting from the state monopoly in the social sphere to private profitoriented and non-governmental organizations;

5) restricting vertical redistribution within the insurance benefits;

6) the reduction of numerous social benefits and tightening the eligibility criteria for these benefits;

7) creating conditions for the private insurance and services market to complement or substitute social security or the public social services system, combined with a wide variety of reimbursement;

8) adapting social services and the whole social policy to the requirements of the market economy;

9) the weaker capabilities of the third sector organizations - as subjects of social policy - in comparison with other EU countries, combined with a weak civil society development;

10) the overwhelming dominance of a neo-liberal and conservative perspective on social policy accompanied by the marginalization of socialist / social democratic policy regimes (Księżopolski 2011, p. 266267).

\footnotetext{
${ }^{1}$ The most popular models by R. Titmuss and G. Esping-Andersen (marginal or residual/liberal; motivational, handmaiden/conservative-corporative; institutional-redistributive/socialdemocratic) underlie his classification (Titmuss 1974; Esping-Andersen 1990).
} 
Table 1. Family Policy against the Background of the Models in the European Union Formed by 2004

\begin{tabular}{|c|c|c|c|c|}
\hline \multirow{2}{*}{ Criteria/Assumptions } & \multicolumn{4}{|l|}{ MODEL } \\
\hline & Scandinavian & Anglo-Saxon & Continental & Southern European \\
\hline State family policy & $\begin{array}{c}\text { Universal access to social services } \\
\text { and transfers according to needs; } \\
\text { active and supporting gender } \\
\text { equality and female participation } \\
\text { in labour market }\end{array}$ & $\begin{array}{c}\text { Limited, narrow scope of services } \\
\text { supporting families. }\end{array}$ & $\begin{array}{l}\text { Passive, supporting male } \\
\text { breadwinner model }\end{array}$ & $\begin{array}{c}\text { Limited, underdeveloped services } \\
\text { and transfers supporting regular } \\
\text { family activities }\end{array}$ \\
\hline Scope of public social services & $\begin{array}{l}\text { Universal, high standard of } \\
\text { services and other transfers }\end{array}$ & Low (selective and facultative) & $\begin{array}{l}\text { Moderate; dependent on } \\
\text { individual statuses at the labour } \\
\text { market (efficiency and seniority) }\end{array}$ & $\begin{array}{l}\text { Very limited; informal market } \\
\text { services }\end{array}$ \\
\hline State interventions & High, protective role & Low; "night watch" & $\begin{array}{c}\text { Low (higher than in Anglo-Saxon } \\
\text { model; social interventions } \\
\text { supporting economic } \\
\text { development); subsidiarity } \\
\end{array}$ & $\begin{array}{l}\text { Various (stable employment } \\
\text { preferred); "soft state" } \\
\text { encouraging clientelism }\end{array}$ \\
\hline Family activity & Low & $\begin{array}{c}\text { Very high (high commodification } \\
\text { rate) }\end{array}$ & High (at the labour market) & $\begin{array}{l}\text { Very high (especially in terms of } \\
\text { labour market exclusion) }\end{array}$ \\
\hline $\begin{array}{c}\text { Stakeholders involved in welfare capacity } \\
\text { building }\end{array}$ & State, society & $\begin{array}{c}\text { Families, local communities, } \\
\text { NGOs-charity }\end{array}$ & families - local authorities - state & $\begin{array}{l}\text { Families, local communities, } \\
\text { church, NGOS - charity }\end{array}$ \\
\hline Countries & $\begin{array}{l}\text { Sweden, Denmark, Norway, } \\
\text { Finland }\end{array}$ & UK, Ireland & $\begin{array}{l}\text { Austria, Belgium, France, the } \\
\text { Netherlands }{ }^{1}, \text { Germany }\end{array}$ & Greece, Spain, Portugal, Italy \\
\hline
\end{tabular}

Source: author's own review on: R. Titmuss, Essays on the Welfare State, Allen and Unwin, London 1974; G. Esping-Andersen, The three worlds of welfare capitalism, Polity Press, Cambridge 1990.

${ }^{1}$ Social Policy in the Netherlands has a lot in common with Scandinavian countries, thus it is by some included into social democratic regimes (R. E. Goodin et.al. 1999, Księżopolski 2011, p. 262). 
Unfortunately, due to the variety of models and opinions on the above mentioned trends and perspectives, finding effective solutions is not easy. At the same time it should be noted that certain types of social policy theoretically common for different groups of countries - reflect the diverse problems and strategies for solving them. This applies especially to the countries of Central and Eastern Europe (Księżopolski 2011, p. 266).

In addition, an important reference point which appears in discussions about the development of family policy in Poland and other European countries is the principle of subsidiarity. This has been implemented in Poland for over two decades, namely from the beginning of the Polish transformation in 1989. It was established in the preamble of the Polish Constitution, which claims that the state is based on "[...] respect of freedom and justice, cooperation between authorities, social dialogue and on the principle of subsidiarity, strengthening the powers of citizens and their communities [...]". The Constitution does not define the principle of subsidiarity, however, citizens' rights are highlighted, adding the role of the state in exercising those rights. On the one hand, the state is mostly identified as an entity creating the appropriate conditions for the functioning of the society as a whole, as well as given groups and individuals through assistance or support. On the other hand, civil duties come down to concern for the common good.

The introduction of the principle of subsidiarity to social and family policy seems relevant, but taking the many possible imperfections of individuals and families under consideration it requires a reasonable approach. As shown in many studies, the state (or any other entity performing services addressed to the family) happens to withdraw its commitments that refer to ensuring the proper conditions for families in the name of "family empowerment". This situation occurred in the first period of systemic transformation in Poland. The shock caused by unemployment, the deep drop in family income, the rise of poverty and the lack of adjustment mechanisms were accompanied by raising expectations for the family's own responsibility instead of family assistance. Therefore it is necessary to define the citizen's responsibility for living conditions, as well as the limits of falling back on self-help grassroots initiatives (e.g. informal support networks). Local communities, especially vulnerable groups, are not capable of solving problems such as unemployment, poverty and the lack of social security. Shifting the burden onto the family or social solidarity may not always prove sufficient. "Communities of poverty and marginalization" occur more and more often. They are unable to change the situation through local action and self-help. Counting on families' selfsufficiency without appropriate institutional support may deepen socioeconomic disparities between families or communities, increasing the marginalization of the poor, bringing the loss of social security, etc. (Szczepaniak 2010, Baarsma 2011, p. 116). 


\section{Concluding Remarks}

The greatest challenge of family policy in Poland is resolving the dilemma whether the neo-liberal direction of changes adopted in Poland is fully justified from the perspective of low fertility rates and the ongoing processes of the deinstitutionalization of the family? Do Polish families - both poor or socially excluded for other reasons, as well as those in a relatively favorable socioeconomic condition - have adequate provisions to take over almost total responsibility for the conditions of their existence without the vital support of local or central government? If so, which of the liberal solutions should be priorities? Some guidance in resolving these dilemmas can indeed be found in specific models of social policy and changes' directions. However, they are not unanimous and do not settle clearly the strategies for families. Moreover, the actual condition of Polish society, including families - both internal and external - additionally prevents realization of existing and often promising solutions.

While seeking consensus on the model of family policy, it should also be noted that certain instruments belong to the scope of state or public interventions in terms of family functioning, which are not universally accepted in the academic and research environment, and even if such interventions should take place at all there is a question regarding their forms and extent, etc. At this point the dilemmas of efficient goods and services redistribution are tackled, both public or private. The multiplicity of ideologies and theories relating to these issues ${ }^{1}$ shows for example that for some, no state interference should shape the conditions in which families are unfunded and they will strive to reduce completely public benefits - both cash and nonfinancial (radical liberals), for others state regulation in specific circumstances is not only justified but necessary (social democrats). Consensus in this matter is important primarily for the two questions posed above: the share of the public sector, market and social development and the responsibilities of the state, the family and other stakeholders in organizing, financing and delivering social benefits (especially services) to families.

In my opinion, due to the diverse socio-economic conditions in Poland that influence families and their progressing de-institutionalization, looking for a model of a "supportive" state (neither "relieving", nor "ignoring") should be a priority both for traditional families (to strengthen their ties), as well as informal relationships (especially when they are planning or have offspring) or single parents outside marriage (mostly women). This model should facilitate not only increasing fertility but also employment rates (especially of women, including young mothers) and thus stabilize the social and material situation of individuals and families. Following this reasoning, it seems that the optimal solutions for family policy in Poland should be sought between the Scandinavian (e.g. Sweden), Continental (e.g. France, the Netherlands) and Anglo-Saxon model (e.g. the UK, Ireland). The Polish family policy model

${ }^{1}$ Useful dilemmas and theoretical background are presented e.g. in: Barr 1993, p. 98-118, Becker 2006, p. 126. 
should be a combination of family responsibility with extensive support from the state (e.g. through transfers of intermediate and/or direct co-financing of social services - mainly to families with children, the disabled and elderly people) followed by labour market initiatives in family policy creation (e.g. tax relief for companies offering childcare facilities). Guidelines for the implementation of such family policy development can be found in family friendly employment directions and work-life balance programs enabling the reconciliation of professional and family life, which are implemented by the Scandinavian and Western European countries to a various extent (OECD , 2011).

We should also bear in mind that family policy is not just actions directed at families (explicite), but also those indirect initiatives in diverse areas of social policy (labour market, housing and others). Family policy should not just be reduced to direct funding, poor families, infant care and kindergarten, which can be commonly observed in our country.. It should be perceived rather as a coherent system of varied instruments addressed at different types of families, with varying needs, functioning in diverse walks of life, etc. This should not mean identifying family policy with social policy or economics with all the detailed policies, but - when thinking about for example employment policy considering not just macroeconomic goals, like the impact of level of employment on economic growth, but also social goals, which in the discussed context means the implications of such a policy for the conditions of creating and the functioning of families. In other words, to see mutual relations between the diverse spheres of social and economic life of families and the economy, i.e. the appropriately understood significance of family policy of the implicite type.

Hence in Poland it is necessary to change the way of thinking about the family and family policy and, at the same time, regard such a policy in terms of a particular investment (as for example in Scandinavian countries), and not just as mere budgetary expenditure/cost as can be observed in Poland.

\section{References}

Barr, N 1993, Ekonomika polityki społecznej, Wydawnictwo Akademii Ekonomicznej, Poznań.

Baarsma, NA 2011, The Europeanisation of International Family Law, T.M.C ASSER PRESS, Netherlands.

Becker, GS 2006, Ekonomia życia, Helion, Gliwice.

Dobry klimat dla rodziny 2013, Offices of the Chancellery of the President. Available from: <http://www.prezydent.pl/download/gfx/prezydent/pl/defaultopisy/3691/1/ 1/polityka_rodzinna_internet_0913.pdf >. [27 October 2014].

OECD 2011, Doing Better for Families. Available from: http://www.oecd.org/social /family/doingbetter [12 October 2014].

Esping-Andersen, G 1990, The three worlds of welfare capitalism, Polity Press, Cambridge. 
Esping-Andersen, G 2010, Społeczne podstawy gospodarki postindustrialnej, WSP TWP, Warszawa.

Eurostat Database. Available from: 〈http://epp.eurostat.ec.europa.eu $>$. [10 April 2014].

Goodin, RE, Headey B, Muffels R \& Dirven H 1999, The real worlds of welfare capitalism, Cambridge University Press, Cambridge.

Grewiński, M \& Kamiński, S 2007, Obywatelska polityka społeczna, WSP TWP, Warszawa.

Księżopolski, M 2011, Polityka społeczna na tle modeli występujacych w Europie, in Europa socjalna. Iluzja czy rzeczywistość?, eds. W Anioł, M Duszczyk \& P.W Zawadzki, ASPRA-JR, Warszawa, pp. 261-285.

Roczniki Demograficzne (edition for the relevant years from 2004 to 2013), GUS, Warszawa.

Socjologia. Przewodnik encyklopedyczny 2008, PWN, Warszawa.

Stiglitz, J 2004, Ekonomia sektora publicznego, PWN, Warszawa.

Spicker, P 2008, Social Policy. Themes and Approaches, The Policy Press, Bristol.

Szczepaniak, J 2010, Subsydiarność $w$ polityce wobec rodziny $w$ warunkach wspótczesnych - między idea a rzeczywistościa, in Wspótczesne wyzwania polityki spolecznej wobec rodziny, eds. A Kubów \& J Szczepaniak, PN UE we Wrocławiu, Wrocław, pp. 31-52.

Titmuss, R 1974, Essays on the Welfare State, Allen and Unwin, London. 